\title{
Study on Electronic Commerce Credit Scoring Model Based on the Dynamic Adjustment of Multi-factors
}

\author{
Xiao Qiang* and Liao Hui \\ Economics and management school, Lanzhou Jiao tong University, \\ 730070, Lanzhou, China \\ *Corresponding author:lzjt_xq@126.com \\ Lzjt_liaohui@126.com
}

\begin{abstract}
With the development of electronic commerce, the credit problem has become a bottleneck for the development of E-commerce, through analysis of E-commerce credit evaluation factors, using the factor analysis and dynamic adjustment mode, construction of electronic commerce credit evaluation model. Through the experimental simulation, the model can effectively reduce the influence of electronic commerce credit due to negative or positive reviews, and further improve the E-commerce credit system, provides a theoretical basis for the development of E-commerce credit scoring system.
\end{abstract}

Keywords: E- commerce, credit scoring, multiple factors, dynamic adjustment

\section{Introduction}

With development of information technology and the social informationization, Ecommerce has been rapid development. China's E-commerce market turnover reached 3.5 trillion Yuan by June 2012, Year-on-year growth of 18.6\% [1]. The online retail sales market turnover is 511.9 billion Yuan, up $46.6 \%$ from a year earlier. However, as the E-commerce rapid development at the same time, E-commerce fraud is become more and more serious, brush poor commentary and good commentary have become a common means to change the credit score in the present E-commerce sites [2,3], easy to misleading consumers, increase number of complaints from E-commerce sites, hindered the development of E-commerce [4, 5]. Based on the current domestic E-commerce credit score research, combining with the characteristics of current website credit score, credit rating model based on Dynamic Adjustment of Multi-factors is put forward, this model can be effectively reduced for the influence of poor commentary and good commentary to network consumers.

\section{Research on Assessment of Electronic Commerce Credit}

On the issue of E-commerce credit evaluation, it can be seen from research of the domestic and foreign, research of E-commerce credit has been from the earliest theory factors analysis gradually transition to the establishment of evaluation index system and model. Scholar Zhang Jialing theoretically analyzed that the credit problems of E-commerce is not only restricted the development of E-commerce transaction, but also changed the consumption patterns of consumers [3]. Scholar Tian Bo puts forward the concept of credit, the connotation and the measurement method, and discusses the electronic commerce credit model. He thinks that we can judge the transaction status through the perception of trust and reputation system model [4]. Scholars Lu Yao-Bin's online trust universal model is put forward by analyzing 
the E-commerce credit framework model, there were analyzed from several consumers, businesses and website, etc., and to determine the influence of these factors on the consumer's shopping [5].

In china in recent years, methods and means of using credit evaluation of E-commerce constantly bring forth the new through the old, On the basis of credit evaluation theory and different types of algorithm, there are two categories of credit evaluation algorithm was proposed, namely the traditional credit evaluation algorithms and artificial intelligence in credit evaluation algorithm. Traditional credit assessment algorithm mainly includes fuzzy theory [6], game theory $[7,8]$, structural equation model and the analytic hierarchy process, etc., $[9,10]$, these algorithms have some advantages, but these models algorithm structure are more complicated, And only used for credit rating of the site, not the credit evaluation on buyers. In artificial intelligence algorithms, neural network algorithm is widely used in the Ecommerce credit evaluation, neural network algorithm has the advantage of training sample data set, but the drawback is that the sample data sets, because the neural network training samples were collected to establish more difficult in the current study, and Sample uncertainty influences the evaluation effect.

Multi-factor dynamic adjustment algorithm is proposed in this paper, from the factors affecting E-commerce credit evaluation, and use dynamic adjustment means, it realizing the various factors in the evaluation model, it avoids the complexity of the conventional algorithm, and avoid the data set is not easy to collect in artificial intelligent algorithm, it improves the reliability of E-commerce credit evaluation and effectiveness

\section{The Electronic Commerce Credit Evaluation Analysis of Multi-factor Influence}

In our country E-commerce began in the $1990 \mathrm{~s}$, however, electronic commerce credit evaluation began in the late 1990s in the B2C and B2B [11]. In a few years, C2C Ecommerce sites like Taobao, Ebay and Paipai have launched its own evaluation system. Evaluation approach is both buyers and sellers of mutual after users to complete the transaction, evaluation scores were accumulated to the user's credit system. This method not only can't accurately response transaction both sides of the credit, also easy to cause brush "bad review" and brush "reputably" phenomenon. Through factor analysis of electronic commerce credit evaluation, it will be able to better improve the evaluation system, at the same time also it can be improve E-commerce transaction system.

\subsection{The current credit evaluation model}

Currently E-commerce sites evaluation is high praise $(+1)$, medium review $(+0)$, bad review (-1) [12,13], although this way can quickly to accumulate for buyers and sellers of credit score, but can't reflect the real evaluation attitude of both sides, and this mode depends on the buyers' subjective, buyers think goods good, will give a high praise; The goods is not good, will give bad review, credit evaluation in the evaluation score has nothing to do with the turnover, credit score is dependent on the number of trading. If single seller in the transaction volume is very big, the growth of the credit score is very low after the deal. Anyway, single assessment factors in the current credit evaluation model, which is not in conformity with the credit development needs of E-commerce. In the long run, it will hinder the development of electronic commerce. 


\subsection{Multiple factors analysis of credit rating}

In order to reflect the E-commerce credit evaluation results, combined with the current Ecommerce credit evaluation mode, E-commerce credit factors are divided into three categories including the seller, the buyer factors and third factors in the paper.

(1) The seller factors

As one of the main transaction, the seller of credit impact is mainly manifested in the buyer's credit evaluation, the transaction amount, transaction time, transaction quality, the trading of goods delivery time and shops operating time and other factors, among these factors, goods delivery time and credit is the inverse proportion. Delivery time is long, its credit is worse. Other factors and credit evaluation is the proportion of positive.

(2) The buyer factors

In the course of the transaction, the buyer is the key to the deal, the buyer for credit impact is mainly manifested in the credit evaluation, purchase frequency, purchase quantity, purchase amount and the seller by the buyer, the buyer's level of education.

(3) The third factors

In the course of the transaction, the third party is often appear as payment's role, but in this paper, the third party except as the original characters, but also taking a supervisory role, so the effect on trust include the buyer's bad credit record of the transaction, the buyer of the abnormal adjustment, abnormal from the buyer, the seller's bad record of the transaction, the seller abnormal transaction times and other factors.

\section{Multi-factor Dynamic Adjustment Model}

\subsection{The seller dynamic adjustment factors analysis}

By analyzing the seller credit form factors, it can be set the seller credit factors for $\mathrm{CS}$, transaction amount is $\mathrm{M}$, trading delivery time is T1, the seller's operating time is $\mathrm{T} 2$, the buyer's credit rating is $\mathrm{F}$, the seller credit factor evaluation model can be defined as:

$$
C_{S}=f_{1}(M)+f_{2}(F)+f_{3}(T 1)+f_{4}(T 2)
$$

Where $f_{1}(M)$ is the volume of transactions to dynamically adjust of the credit score, $f_{2}(F)$ is the buyer evaluation of credit score, $f_{3}(T 1)$ is the delivery time of the credit score, $f_{4}(T 2)$ is the shop operation time of credit score. As shown in the following table.

Table 1. $f_{1}(M)$ the seller transactions dynamically adjust the score table

\begin{tabular}{cc}
\hline The amount of the transaction & Credit scores \\
\hline $0-200$ & 1 \\
$201-500$ & 2 \\
$501-1000$ & 3 \\
$1001-5000$ & 5 \\
$5001-10000$ & 8 \\
$10001-50000$ & 15 \\
$50001-100000$ & 30 \\
$>100000$ & 50 \\
\hline
\end{tabular}


Table 2. $f_{2}(F)$ the buyer's credit evaluation score

\begin{tabular}{ccc}
\hline $\begin{array}{c}\text { buyers } \\
\text { credit }\end{array}$ & $\begin{array}{c}\text { Buyer credit } \\
\text { index }\end{array}$ & Credit scores \\
\hline $0-10$ & 1 & \\
$11-20$ & 2 & The buyer score $\times$ buyer credit \\
$21-30$ & 3 & index \\
$\ldots$ & $\ldots$ & \\
$91-100$ & 9 & \\
$>100$ & 10 & \\
\hline
\end{tabular}

Table 3. $f_{3}(T 1)$ the delivery time and quality of the credit score

\begin{tabular}{cc}
\hline Seller's credit & Credit scores \\
\hline Both sides agreed period of time & 1 \\
Both sides agreed period of time & -1 \\
The two sides agreed goods quality & 1 \\
Product quality not up to the two sides & -1 \\
\hline
\end{tabular}

Table 4. $f_{4}^{(T 2)}$ website operation time credit scores

\begin{tabular}{cc}
\hline The operating time (months) & Credit scores \\
\hline 1 & 5 \\
2 & 10 \\
3 & 15 \\
$\ldots$ & $\ldots$ \\
$\mathrm{n}$ & $\mathrm{n}$ \\
\hline
\end{tabular}

\subsection{The buyer of the dynamic adjustment factor analysis}

Through the analysis, it can set the buyer credit factors for $\mathrm{B}_{\mathrm{S}}$, purchase amount is the M1, the seller evaluation factors is F1, buyers evaluation is $\mathrm{P}$, the buyer credit factors can be defined as:

$$
B_{S}=f_{5}(M 1)+f_{6}(F 1)+f_{7}(P)
$$

Where $f_{5}(M 1)$ is the buyer credit score on purchase amount, $f_{6}(F 1)$ is the seller's evaluation factors of the credit score, $f_{7}(P)$ is the number of evaluations of the credit score. The credit evaluation index is the same as in $\mathrm{D}, \mathrm{Z}$ and table 1 , table 2 , evaluation are listed in the following table:

Table 5. $f_{7}(P)$ the buyer evaluation credit scores

\begin{tabular}{cc}
\hline The number of evaluations & Credit scores \\
\hline To evaluate & 1 \\
Don't evaluation & 0 \\
\hline
\end{tabular}




\subsection{Third party factors analysis of dynamic adjustment}

The seller and the buyer credit analysis values, combined with third party credit score, and then get the seller and the buyer's credit value. Third party dynamic adjustment value for $\mathrm{D}_{\mathrm{S}}$ :

$$
\left\{\begin{array}{l}
D_{S 1}=f_{8}(C)+f_{9}(B 1)+f_{10}(B 2) \quad \text { Seller's credit score using third party dynamic adjustment } \\
D_{S 2}=f_{11}(B)+f_{12}(C 1)+f_{13}(C 2) \quad \text { Buyer's credit score using third party dynamic adjustment }
\end{array}\right.
$$

Where $f_{8}(C)$ is the seller's credit score on abnormal record, $f_{9}(B 1)$ and $f_{10}(B 2)$ is the credit score, which means abnormal good praise and abnormal Poor praise of the buyer to the seller, $f_{11}(B)$ is buyer's the credit score on abnormal record, $f_{12}(C 1)$ and $f_{13}(C 2)$ is the credit score, which means abnormal good praise and abnormal Poor praise of the seller to the buyer.

Table 6. $f_{8}(C)$ Abnormal record score

\begin{tabular}{cc}
\hline $\begin{array}{c}\text { The seller (buyer) exception record } \\
\text { number }\end{array}$ & Credit scores \\
\hline 0 & 0 \\
1 & -5 \\
2 & -10 \\
3 & -20 \\
4 & -40 \\
5 & -80 \\
$\ldots$ & $\ldots$ \\
$>10$ & The seller (buyer) credit score are cleared \\
\hline
\end{tabular}

For abnormal evaluation, in this article it is defined as within a certain time or period of regularity for sellers (buyers) suddenly appeared continuously high praise (bad review), so can't really reflect the sellers (buyers) credit. In order to better prevent bad review or high praise to the sellers (buyers) the influence of the credit, in this model, it can using evaluation data mining algorithms ( $\mathrm{K}$ - means algorithm) [14], the time of credit scoring methods, namely by the hour, day and month of buyers (sellers) anomaly monitoring scores and data, to realize calculating credit scores, the greatest degree reflected buyers (sellers) credit scores, as follows : 
Table 7. Abnormal evaluation credit scores

\begin{tabular}{ccc}
\hline $\begin{array}{c}\text { Evaluation of anomaly } \\
\text { types }\end{array}$ & Detection period & Credit scores \\
\hline good comment & Day (detection per hour data) & $\sum \frac{1^{x}}{8}(x=1,2,3,4 \cdots)$ \\
& $\begin{array}{c}\text { Month (detection according to } \\
\text { daily data) }\end{array}$ & $\sum \frac{1}{4}^{x}(x=1,2,3,4 \cdots)$ \\
& Years (detection by monthly data) & $\sum \frac{1^{x}}{2}(x=1,2,3,4 \cdots)$ \\
\hline Bad comment & Day (detection per hour data) & $\sum \frac{1^{x}}{8}(x=1,2,3,4 \cdots)$ \\
& Month (detection according to \\
daily data) & $\sum \frac{1^{x}}{4}(x=1,2,3,4 \cdots)$ \\
& Years (detection by monthly data) & $\sum \frac{1^{x}}{2}(x=1,2,3,4 \cdots)$ \\
\hline
\end{tabular}

\subsection{Factors of the dynamic adjustment model}

According to the analysis of the buyer, the seller and the third party factors, establish the multi-factor dynamic adjustment of credit evaluation model:

$$
\begin{cases}C_{i}=D_{S 1}+C_{i-1} & \left(i=1,2, \cdots n ; C_{0}=0\right) \\ B_{i}=D_{S 2}+B_{i-1} & \left(i=1,2, \cdots n ; B_{0}=0\right)\end{cases}
$$

This model can realize the buyer and the seller's credit tired, at the same time, it can be dynamic adjustment through a third party factors. When evaluation is abnormal, the buyer and the seller's credit score is not due to abnormal change happens suddenly appear credit increase and decrease. It can be more real reflect the E-commerce transactions on both sides of the credit score.

\section{Experimental Verification}

In order to verify the validity of the model, at the same time, this model can better applied to the website shops and website user credit evaluation. This model was being simulation calculation and the simulation results were being graphical display. As a result of current E-commerce credit scoring and credit scores in this model there are differences, so in the experiment, the data is according to the factors in this algorithm, simulation credit evaluation data in electronic business transactions. Namely, to establish the virtual trading platform, respectively specified experiment group trading (buying users and anomaly evaluation).

In virtual transactions, assuming that the seller and the buyer's initial credit value is 0 , the seller and the buyer evaluation score that a high praise review is 1 minute, medium review is 0 , bad review is - 1 , after completion of the buyer and the seller deals, mutual evaluation. Specify two experimenters are online sellers, 30 subjects are buyers, and each buyer has virtual currency of RMB 5000. Specify five experimenters 
separately brush bad review and high praise. 30 participants randomized to deal. Within a month, brush reputably and bad reviews were completed respectively, reduce or promote the online store credit. Designated seller has two abnormal records. Specifies five buyers have abnormal transactions from 1 to 5 times, specify the website operation time is 1 months. Transaction records screenshot as shown in the figure below:

\begin{tabular}{|c|c|c|c|c|c|c|c|c|c|c|c|c|c|}
\hline 序号 & 交易时间 & 卖家用户名 & \begin{tabular}{|c} 
卖方营 \\
运时间 \\
(月)
\end{tabular} & $\begin{array}{c}\text { 交易金额 } \\
\text { (元) }\end{array}$ & $\begin{array}{l}\text { 卖方配 } \\
\text { 送时间 }\end{array}$ & $\begin{array}{l}\text { 卖方商 } \\
\text { 品质里 }\end{array}$ & $\begin{array}{l}\text { 卖方异 } \\
\text { 常记录 }\end{array}$ & $\begin{array}{l}\text { 卖方 } \\
\text { 评价 }\end{array}$ & $\begin{array}{l}\text { 卖方信 } \\
\text { 用评分 }\end{array}$ & 买家用户名 & \begin{tabular}{|} 
买方异 \\
常记录
\end{tabular} & $\begin{array}{l}\text { 买方 } \\
\text { 评价 }\end{array}$ & $\begin{array}{l}\text { 买方信 } \\
\text { 用评分 }\end{array}$ \\
\hline 1 & $2012-11-1 \quad 10: 56 \mathrm{AM}$ & 201132001 & 5 & 180 & 1 & 1 & 0 & 1 & 1 & 201132002 & 0 & 1 & 1 \\
\hline 2 & 2012-11-1 11:02 AM & 201132001 & 5 & 360 & 1 & 1 & 0 & 1 & 1 & 201132013 & 0 & 1 & 1 \\
\hline 3 & 2012-11-1 11:13 AM & 201132001 & 5 & 1500 & 1 & 1 & 0 & 1 & 1 & 201132024 & 0 & 1 & 1 \\
\hline 4 & $2012-11-14: 43 \mathrm{PM}$ & 201132001 & 5 & 400 & 1 & 1 & 0 & 1 & 1 & 201132015 & 0 & 1 & 1 \\
\hline 5 & 2012-11-1 5:32 PM & 201132001 & 5 & 550 & 1 & 0 & 0 & 1 & 1 & 201132026 & 0 & 1 & -1 \\
\hline 6 & $2012-11-18: 12 \mathrm{PM}$ & 201132001 & 5 & 180 & 1 & 1 & 0 & 1 & 1 & 201132007 & 0 & 1 & 1 \\
\hline 7 & 2012-11-2 1:09 PM & 201132001 & 5 & 3000 & 1 & 1 & 0 & 1 & 1 & 201132008 & 0 & 1 & 1 \\
\hline 8 & $2012-11-2 \quad 7: 30 \mathrm{PM}$ & 201132001 & 5 & 450 & 1 & 1 & 0 & 1 & 1 & 201132019 & 0 & 1 & 1 \\
\hline 9 & 2012-11-2 7:42 PM & 201132001 & 5 & 50 & 1 & 1 & 0 & 1 & 1 & 201132010 & 0 & 1 & 1 \\
\hline 10 & 2012-11-2 12:00 AM & 201132001 & 5 & 1500 & 1 & 1 & 0 & 1 & 1 & 201132030 & 0 & 1 & 1 \\
\hline 11 & 2012-11-2 9:00 PM & 201132001 & 5 & 180 & 1 & 1 & 0 & 1 & 1 & 201132031 & 0 & 1 & 1 \\
\hline 12 & 2012-11-3 9:02 AM & 201132001 & 5 & 400 & 0 & 1 & 0 & 1 & 1 & 201132013 & 0 & 1 & 0 \\
\hline 13 & 2012-11-3 9:43 AM & 201132001 & 5 & 180 & 1 & 1 & 0 & 1 & 1 & 201132004 & 0 & 1 & 1 \\
\hline 14 & $2012-11-3 \quad 10: 04 \mathrm{AM}$ & 201132001 & 5 & 2000 & 1 & 1 & 0 & 1 & 1 & 201132015 & 0 & 1 & 1 \\
\hline 15 & $2012-11-3 \quad 10: 06 \mathrm{AM}$ & 201132001 & 5 & 450 & 1 & 1 & 0 & 1 & 1 & 201132022 & 0 & 1 & 1 \\
\hline 16 & $2012-11-3 \quad 11: 34 \mathrm{AM}$ & 201132001 & 5 & 180 & 1 & 1 & 0 & 1 & 1 & 201132017 & 0 & 1 & 1 \\
\hline 17 & 2012-11-3 4:21 PM & 201132001 & 5 & 360 & 1 & 1 & 0 & 1 & 1 & 201132018 & 0 & 1 & 1 \\
\hline 18 & 2012-11-3 4:46 $\mathrm{MM}$ & 201132001 & 5 & 400 & 1 & 1 & 0 & 1 & 1 & 201132004 & 0 & 1 & 1 \\
\hline 19 & 2012-11-3 5:03 PM & 201132001 & 5 & 800 & 1 & 1 & 0 & 1 & 1 & 201132008 & 0 & 1 & 1 \\
\hline
\end{tabular}

Figure 1. Website buyers and sellers trading record table

In experiment, in order to verify the feasibility of the algorithm model, the conventional algorithm and the multi-factor dynamic adjustment algorithm are compared. Conventional algorithms are defined in the present E-commerce credit score, accumulated credit scores. Multi-factor dynamic adjustment algorithm refers to the credit score calculation using the brush and brush bad review data from specific data, verify the results in Figure 2 and Figure 3:

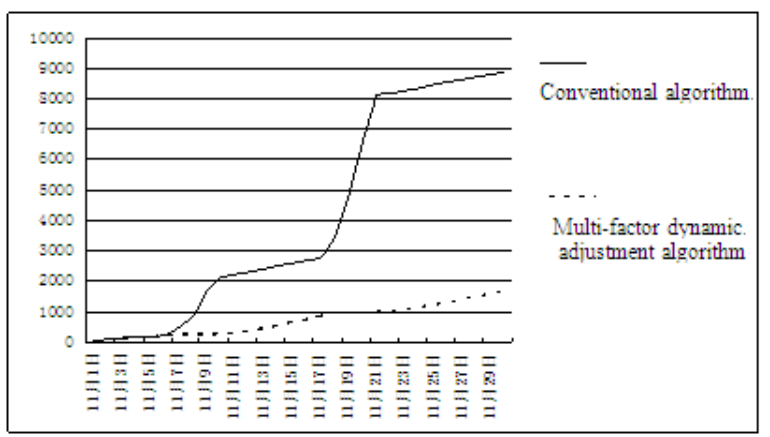

Figure 2. Abnormal brush reputably credit score comparison on conventional algorithm and multi-factor dynamic adjustment algorithm 


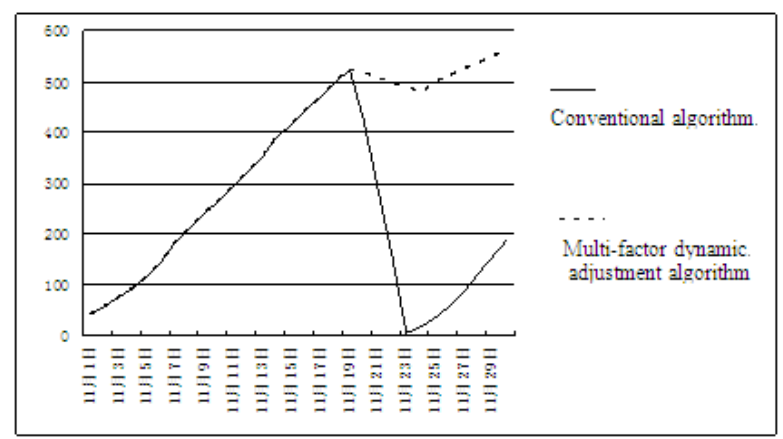

Figure 3. Abnormal brush poor credit scores comparison on conventional algorithm and multi-factor dynamic adjustment algorithm

As you can see from Figure 2, in a month when the shop had experienced two brush reputably periods, the first period brush reputably were low, second hours after the first time from accumulation, credit scoring has increased, purchases the user also can be raised, in a month credit increased from 0 to 8000 . But after the algorithm, because the model is proposed in the dynamic adjustment of the third factors, combined with the outlier data mining algorithm, find out the brush reputably possible data points, thus to reduce the credit scoring way, avoid credit growth.

As you can see from Figure 3, the conventional algorithm due to defects in algorithm itself, lead to business in the seller cannot meet the requirements of each other, will focus on the brush. Shops in the short term credit sharply reduced, leading to decline in trading volume. But after the algorithm proposed in this paper, can see that although the credit will decline, but shops credit won't have too big change, to avoid losses due to poor shops and brush.

\section{Conclusions}

Through the experiment, in the electronic commerce credit score, multi-factor dynamic adjustment algorithm can improve the electronic commerce as the brush or brush from poor effect on credit, avoid shops and users of credit is not true. But we should also see, in this paper the experimental data is generated by a virtual trade platform, and the feasibility of algorithm on real transaction data still need further verification, at the same time in this algorithm, the key function is to dynamically adjust the third factors, the core is abnormal trading credit evaluation data mining. In the future of electronic commerce credit research, it is mainly study on abnormal data mining algorithm, and it better improve the algorithm in this paper.

\section{Acknowledgements}

This work is supported National Funds of Social Science (NO. 08XTQ010) by to Qian Xiao-dong respectively and project supported by young scholars science Foundation of LAN Zhou Jiao Tong university (NO.2011044). 


\section{References}

[1] G. Ran, "Problems and Countermeasures of China's e-commerce credit evaluation", China Business, vol. 23, (2009), pp. 32-33.

[2] J. -x. Hu and Z. -j. Jiang, "A Trust Evaluation Model for C2C E-Commerce Based on BP Neural Network", Library and Information Service, vol. 56, no. 10, (2012), pp. 131-137.

[3] G. -1. Zhang, "On Credit Management of E-Commerce", The Theory and Practice of Finance and Economics, no. 5, (2002), pp. 105-107.

[4] T. Bo and T. Zheng, "Study on the Trust Model of E-commerce", Journal of Information, vol. 26, no. 4, (2007), pp. 42-44.

[5] Y. -B. Lu and T. Zhou, "Comparative analysis of online trust model”, Science and Technology Management Research, no. 11, (2005), pp. 131-134.

[6] S. -f. Peng and Y. Tian, "Application of Fuzzy AHP in Credit Evaluation of Small Industrial Enterprises", Journal of Chongqing Institute of Technology (Natural Science Edition), vol. 22, no. 1, (2008), pp. 131-134.

[7] W. -x. Hu and C. Wang, "Review of Studies on Game Analysis of China's E-Commerce Credit Problems", Electronic Science and Technology, no. 11, (2012), pp. 121-124.

[8] X. -W. Ban, W. Jiang and H. Shi, "Analysis of the Credit System of E-business Based on the Game Theory", Journal of University of Electronic Science and Technology of China (Social Sciences Edition), no. 4, (2008), pp. 54-57.

[9] H. Qiong and H. Gang, "Analysis and Research on the model of the C2C electronic commerce website credit evaluation”, China Management Informationization, vol. 11, no. 11, (2008), pp. 96-98.

[10] H. -R. Xu and F. -y. Wang, "Dynamic trust evaluation model for C2C electronic commerce", Journal of Shangdong University of Technology (natural Science Edition), vol. 26, no. 1, (2012), pp. 74-77.

[11] Q. Yan, “An evaluation model of electronic commerce credit improvement”, Popular Science \& Technology, no. 6, (2010), pp. 14-16.

[12] H. Qiong and H. Gang, "C2CAnalysis and study of e-commerce credit evaluation model", China Management Informationization, no. 11, (2008), pp. 96-98.

[13] Z. Lei, Z. Li and N. -n. Wu, "E-commerce credit evaluation system Based on C2C", Popular Business, vol. 109, no. 1, (2010), pp. 147-149.

[14] Q. Xiao and X. -D. Qian, "Web Users Association Rule Mining Algorithm Based on K-means Algorithm", Library and Information Service, vol. 55, no. 16, (2011), pp. 136-139.

\section{Authors}

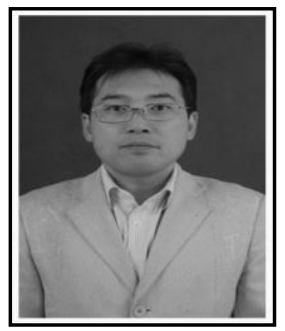

Xiao Qiang received the master degree from the school of information and electrical engineering, Lan Zhou Jiao tong University, in 2007. He is currently working toward the PhD degree in the school of Traffic and Transportation, Lan Zhou Jiao tong University, Lanzhou. His research interests include data mining, Ecommerce and information system.

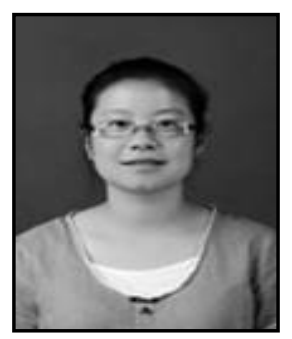

Liao Hui received the BS degree from the school of Economics and Management Lan Zhou Jiao tong University, in 2011. He is currently working toward the master degree in the school of Economics and Management; Lan Zhou Jiao tong University, Lanzhou. She research interests include business management, Ecommerce and information system. 
International Journal of Hybrid Information Technology Vol.6, No.6 (2013) 